\title{
Persistence of chlorpyrifos in greenhouse air
}

\section{Persistência do inseticida clorpirifós no ar em casa de vegetação}

\section{Lia Emi Nakagawa ${ }^{*}$, Marcos Roberto Potenza', Taysa Harue Ichirraro', Solange Papini²}

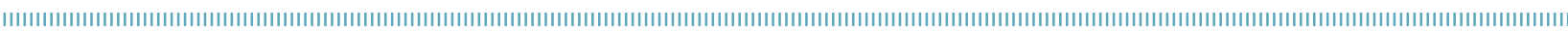

\begin{abstract}
Organophosphate pesticides are among those with the highest acute toxicity and are available on the market and used in several regions of Brazil. The concentration and residence time of the organophosphate pesticide, chlorpyrifos, in the air after application in a greenhouse were investigated. For more than $24 \mathrm{~h}$, the chlorpyrifos remained in the greenhouse air at concentrations three times above the occupational exposure limit and was still detectable four days later.
\end{abstract}

KEYWORDS: organophosphate insecticides, occupational exposure, re-entry period.
RESUMO: Os inseticidas organofosforados estão entre os agrotóxicos de maior toxicidade aguda disponíveis no mercado e são usados em várias regióes do Brasil. Avaliaram-se a concentração e o tempo de permanência do inseticida organofosforado clorpirifós no ar, após aplicação em uma casa de vegetação. O clorpirifós permaneceu no ar da casa de vegetação em concentração três vezes acima do limite de exposição ocupacional por mais de 24 horas, e ainda foi detectado após quatro dias.

PALAVRAS-CHAVE: inseticidas organofosforados, exposição ocupacional, período de reentrada. 
Pesticides are related to acute poisoning, chronic diseases, and reproductive problems. It is estimated that, among workers in developing countries, pesticides annually cause 70 thousand fatal acute and chronic poisonings and at least 7 million nonfatal acute and chronic diseases (FARIA et al., 2007). Brazil has been the largest consumer of pesticides in the world since 2008 and is responsible for $86 \%$ of their consumption in Latin America (Santana et al., 2013). Data from the Federal Ministry of Health show that from 2008 to 2013, an annual average of 1,560 confirmed cases of poisoning, exposure, and adverse reaction to pesticides occurred (BrasiL, 2014).

Organophosphates are among the most acutely toxic pesticides available on the market, and the registrations of different active ingredients for such have been cancelled in several countries, including Brazil (PAsIANI et al., 2012). Organophosphates are acetylcholinesterase inhibitors, and exposure to these pesticides causes adverse health effects such as nausea, bronchoconstriction, sialorrhea, hypertension, and tremors, in addition to affecting the central nervous system (Pasiani et al., 2012). Of the total deaths caused by pesticide poisoning in the State of São Paulo, from 1998 to 2005, 20.9\% corresponded to organophosphate products (São Paulo, 2014).

Nevertheless, because of their efficiency, relatively low cost, and absence of bioaccumulation in the ecosystem, organophosphates are still widely used, despite the availability of other classes of pesticides (COSTA, 2006). Organophosphates are used extensively in agriculture in different regions of Brazil (FARIA et al., 2009; Stroparo; Braguini, 2011; Pasiani et al., 2012; Ribeiro et al., 2012), probably due to the large number of brands still available on the market and factors such as low cost and traditional use by farmers (Lima et al., 2011).

It is estimated that, in Brazil, production of flowers, fruits, and vegetables in protected environments, such as greenhouses, occupies approximately 26,000 hectares, half of which are located in the State of São Paulo (Figueiredo, 2011). In protected cultivation, the use of synthetic chemical compounds is the most common control measure, and is often believed to be the most effective for pest control (VIDA et al., 2004). However, information such as efficiency, dosage, application intervals, persistence, and confidence interval is available only for crops in conventional cultivation and are scarce for protected cultivation (VIDA et al., 2004). Occupational exposure to pesticides may be prolonged and intensified by environmentally specific conditions in protected cultivation such as high temperature, high humidity, and poor ventilation (JUREWICZ et al., 2009; Ribeiro et al., 2012). Furthermore, as protected cultivation requires intensive care, workers are exposed more frequently to pesticides, especially those dispersed in confined areas (Siebers; Mattusch, 1996). Despite this fact, there are few studies in this regard and, in Brazil, there are no specific guidelines or regulations for greenhouse activities (Ribeiro et al., 2012).
The health risk to a worker who performs activities inside closed places where pesticides are used, such as greenhouses and other protected environments, may be estimated by measuring the concentration of these products in the environment. Determining an appropriate re-entry period ensures that a worker can re-enter the treated area safely without personal protective equipment (PPE) (CHOI et al., 2013). However, specific re-entry periods for production in protected cultivation have not been established (USEPA, 2006).

Despite the possible health risks related to re-entry into greenhouses after the application of pesticides, few studies have been carried out regarding the persistence of pesticides in a protected cultivation environment (HatZILAZAROU et al., 2004). In this study, we evaluate the concentration and permanence time of the organophosphate pesticide, chlorpyrifos in the air after its application inside a greenhouse, to estimate the risk of exposure of a worker in this environment.

The study was conducted at the Biologic Institute (São Paulo, Brazil) during the summer time, in a glass experimental greenhouse with an area of $48 \mathrm{~m}^{2}(10 \times 4.8 \mathrm{~m})$ and a volume of $168 \mathrm{~m}^{3}$. During the study, the greenhouse remained unventilated and fully closed. Inside the greenhouse, the temperature and relative humidity ranged from $30.0^{\circ} \mathrm{C}$ to $30.8^{\circ} \mathrm{C}$ and from 61.6 to $70.1 \%$, respectively.

The pesticide used in the study was a commercial product, available on the market as an emulsifiable concentrate formulation, containing chlorpyrifos, at the concentration of $480 \mathrm{~g} / \mathrm{L}$, as the active ingredient. Chlorpyrifos is an organophosphate insecticide, formicide, and acaricide, with authorized agricultural use for foliar and soil applications for different crop cultures (ANVISA, 2014). It has $1.87 \times 10^{-5} \mathrm{mmHg}$ vapor pressure at $20^{\circ} \mathrm{C}$ (USEPA, 2006), is moderately toxic by inhalation (USEPA, 2006), and is one of the 10 most marketed active ingredients with insecticidal action in Brazil (IBAMA, 2009).

The product was applied at a dose of $100 \mathrm{~mL}$ in $10 \mathrm{~L}$ of water, as recommended by the manufacturer, with a manual compression spray, at $1.50 \mathrm{~m}$ above the floor of the greenhouse. A spray nozzle with a flat fan tip produced droplets with a volume median diameter calculated to be between 200 $\mu \mathrm{m}$ and $400 \mu \mathrm{m}$. Immediately after application and at 24,48 , 72 , and $96 \mathrm{~h}$ post-application, air samples were collected at a height of $1.80 \mathrm{~m}$ from the greenhouse floor using a Supelco polyurethane foam (PUF) ORBO ${ }^{\text {TM }} 1000$ attached to a vacuum pump with a flow of $6 \mathrm{~L} / \mathrm{min}$ operating for $5 \mathrm{~min}$. This setup allowed for the sampling of the pesticide in a volume of $30 \mathrm{~L}$ of air. The pesticide was extracted from the PUF cartridge with $60 \mathrm{~mL}$ of ethyl acetate using a $40-\mathrm{kHz}$ ultrasound bath for $6 \mathrm{~min}$. The extract was concentrated to dryness and then dissolved in $1.5 \mathrm{~mL}$ of methanol. This solution was filtered through a $45-\mu \mathrm{m}$ syringe filter and then analyzed by high-performance liquid chromatography (HPLC). The chromatographic analysis was performed using an HPLC system 
(Dionex UltiMate ${ }^{\bullet} 3000$ ), with a C18 column, mobile phase of methanol:water of 82:18 (v/v), $1 \mathrm{~mL} / \mathrm{min}$ flow, temperature of $35^{\circ} \mathrm{C}$, UV detector wavelength of $275 \mathrm{~nm}$, and linear calibration curve calculated from concentrations of $0.4,0.8$, $1.6,3.2$, and $6.4 \mu \mathrm{g} / \mathrm{mL}$.

The chlorpyrifos applied inside the greenhouse remained in the air throughout the study period. The highest concentrations were found immediately after the application and after 24 h. Over time, the product dissipated; however, even after $96 \mathrm{~h}$, it was still detected in the ambient air (Fig. 1). Hatzilazarou et al. (2005) reported the highest concentrations of chlorpyrifos $2 \mathrm{~h}$ after the application $\left(7.1 \mu \mathrm{g} / \mathrm{m}^{3}\right)$ and a decrease in concentration in the following days, reaching $0.16 \mu \mathrm{g} / \mathrm{m}^{3}$ after 6 days. In another study, the concentration of chlorpyrifos in the air decreased by $50 \% 3 \mathrm{~h}$ after the application, and after $2 \mathrm{~h}$ of ventilation, the pesticide was not detected (GUARDino et al., 1998). The variation in the concentration of chlorpyrifos among these studies may be explained by the difference in climatic conditions and greenhouse characteristics. In this study, the characteristically high temperatures of summer, relatively small size of the greenhouse, and lack of ventilation promoted the volatilization of chlorpyrifos and hampered its dissipation. All these factors increase the risk of

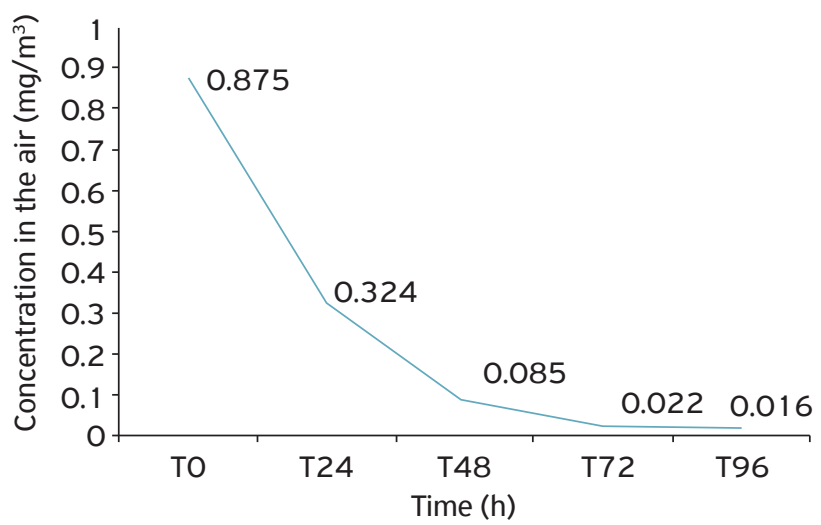

Figure 1. Chlorpyrifos pesticide concentration in the greenhouse air. exposure to workers when they return to the environment after product application.

According to BROUwER et al. (1992), risk to a worker's health exists when the product concentration exceeds the occupational exposure limit. The occupational exposure limit, called a threshold limit value (TLV), set by the American Conference of Governmental Industrial Hygienists for chlorpyrifos in the form of vapor or inhalable aerosols, is $0.1 \mathrm{mg} / \mathrm{m}^{3}$ (CHristensen et al., 2009). In this study, the concentration of chlorpyrifos in the air, $24 \mathrm{~h}$ after the application, was $0.324 \mathrm{mg} / \mathrm{m}^{3}$, which exceeds the TLV over three-fold. After $48 \mathrm{~h}$, this value decreased to $0.085 \mathrm{mg} / \mathrm{m}^{3}$, which is below the occupational exposure limit. Therefore, the organophosphate pesticide chlorpyrifos did not dissipate, and remained in the greenhouse air at a concentration three times higher than the established occupational exposure limit for more than $24 \mathrm{~h}$.

In the specific conditions of this study, the safe return of a worker without PPE to the treated environment should only occur $48 \mathrm{~h}$ after spraying of the product. The re-entry interval in open areas established by the United States Environmental Protection Agency (USEPA) to environments treated with chlorpyrifos ranges from $24 \mathrm{~h}$ to 10 days, depending on the environment. However, there is no specific re-entry interval for protected cultivation environments (USEPA, 2006).

Considering the toxicity of chlorpyrifos, the absence of a specific re-entry interval for greenhouses, and the fact that this pesticide is widely used in Brazil, it is important to adopt preventive measures, such as ventilation of the environment, use of PPE, and a proper reentry interval, to ensure a worker's safety after the application of this pesticide in a greenhouse.

\section{ACKNOWLEDGMENTS}

We acknowledge Edvaldo José de Almeida for his indispensable collaboration during the execution of this study and the National Council for Scientific Development (CNPq) for granting a scientific initiation scholarship to Taysa Harue Ichirraro.

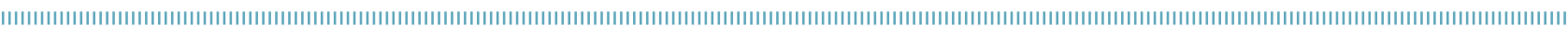
REFERENCES

ANVISA. Agência Nacional de Vigilância Sanitária. Monografías de produtos agrotóxicos. Disponível em:<http://www.anvisa. gov.br/toxicologia/monografias/index.htm> Acesso em: 7 nov. 2014.

BRASIL. Ministério da Saúde, Secretaria de Vigilância em Saúde, DATASUS. Disponível em <http://dtr2004.saude.gov.br/ sinanweb/tabnet/tabnet?sinannet/iexogena/bases/Intoxbrnet. def.> Acesso em: 02 nov. 2014.
BROUWER, D.H.; DE VREEDE, J.A.F.; RAVENSBERG, J.C.; ENGEL, R.; VAN HEMMEN, J.J. Dissipation of aerosols from greenhouse air after application of pesticides using a low-volume technique. Implications for safe re-entry. Chemosphere, v.24, n.9, p.1157-1 169, 1992.

CHOI, H.; BYOUN, J.Y.; KIM, J.H. Determination of Reentry Interval for Cucumber Harvesters in Greenhouse after Application of Insecticide Methidathion. Journal of the Korean Society for Applied Biological Chemistry, v.56, p.465-467, 2013. 
CHRISTENSEN, K.; HARPER, B.; LUUKINEN, B.; BUHL, K.; STONE, D. Chlorpyrifos General Fact Sheet. National Pesticide Information Center, Oregon State University Extension Services. 2009. 17p. Disponível em: <http://npic.orst.edu/factsheets/chlorptech.pdf > Acesso em: 08 nov. 2014.

COSTA, L.G. Current issues in organophosphate toxicology. Clinica Chimica Acta, v.366, n.1-2, p.1-13, 2006.

FARIA, N.M.X.; FASSA, A.G.; FACCHINI, L.A. Intoxicação por agrotóxicos no Brasil: os sistemas oficiais de informação e desafios para realização de estudos epidemiológicos. Ciência e Saúde Coletiva, v.12, 25-38, 2007.

FARIA, N.M.X.; ROSA, J.A.R..; FACCHINI, L.A. Intoxicação por agrotóxicos entre trabalhadores rurais de fruticultura, Bento Gonçalves, RS. Revista de Saúde Pública, v.43, p.335-44, 2009.

FIGUEIREDO, G. Panorama da Produção em Ambiente Protegido. Casa da Agricultura, n.2, p.10-11, 2011.

GUARDINO, X.; OBIOLS, J.; ROSSEL, M.G.; FERRAN, A.; SERRA, C. Determination of chlorpyrifos in air, leaves and soil from a greenhouse by gas-chromatography with nitrogen-phosphorus detection, high-performance liquid chromatography and capillary electrophoresis. Journal of Chromatography A, v.823, n.1-2, p.91-96, 1998.

HATZILAZAROU, S.P.; CHARIZOPOULOS, E.T.; PAPADOPOULOUMOURKIDOU, E.; ECONOMOU, A.S. Dissipation of three organochlorine and four pyrethroid pesticides sprayed in a greenhouse environment during hydroponic cultivation of gerbera. Pesticide Management Science, v.60, n.12, p. 1 197-1204, 2004.

IBAMA. Instituto Brasileiro do Meio Ambiente e dos Recursos Naturais Renováveis. Produtos agrotóxicos e afins comercializados em 2009 no Brasil - Uma abordagem ambiental. Disponível em: <http://www.ibama.gov.br/phocadownload/Qualidade_Ambiental/ produtos_agrotoxicos_comercializados_brasil_2009.pdf > Acesso em: 22 out. 2014 .

JUREWICZ, J.; HANKE, O.; SOBALA, W.; LIGOCKA, D. Assessment of the dermal exposure to azoxystrobin among women tending cucumbers in selected Polish greenhouses after restricted entry intervals expired - the role of the protective gloves. International Journal of Occupational Medicine and Environmental Health, v.22, n.3, p.261-267, 2009.
LIMA, A.C.S.; SOUZA, C.Z.F.; OLIVEIRA, A.H.C.; ALVES, J.M.A.; CORREIA, R.G. Diagnóstico fitossanitário e de práticas associadas ao uso de agrotóxicos nas hortas em ambiente protegido em Boa Vista - Roraima. Revista Agro@mbiente On-line, v.5, n.2, p.124-133, 2011.

PASIANI, J.O.; TORRES, P.; SILVA, J.R.; DINIZ, B.Z.; CALDAS, E.D. Knowledge, Attitudes, Practices and Biomonitoring of Farmers and Residents Exposed to Pesticides in Brazil. International Journal of Environmental Research and Public Health, v.9, n.9, p.3051-3068, 2012.

RIBEIRO, M.G.; COLASSO, C.G.; MONTEIRO, P.P.; PEDREIRA FILHO, W.R.; YONAMINE, M. Occupational safety and health practices among flower greenhouses workers from Alto Tietê region (Brazil). Science of the Total Environment, v.416, p.121-126, 2012.

SÃO PAULO. Secretaria de Estado da Saúde, Centro de Vigilância Epidemiológica - CVE. Disponível em: <http://www.cve.saude. sp.gov.br/htm/doma/agro_obcirc9805.htm> Acesso em: 02 nov. 2014.

SANTANA, V.S.; MOURA, M.C.P.; NOGUEIRA, F.F. Mortalidade por intoxicação ocupacional relacionada a agrotóxicos, 2000-2009, Brasil. Revista de Saúde Pública, v.47, n.3, p. 598-606, 2013.

SIEBERS, J.; MATTUSCH, P. Determination of airborne residues in greenhouses after application of pesticides. Chemosphere, v.33, n.8, p.1597-1607, 1996

STROPARO, L.F.; BRAGUINI, W.L. Avaliação da exposição à organofosforados entre produtores de tabaco de uma localidade do município de Irati-Paraná. Publicatio UEPG: Ciências Exatas e da Terra, Ciências Agrárias e Engenharias, v.17, p.39-50, 2011.

USEPA. United States Environmental Protection Agency. Reregistration Eligibility Decision (RED) for Chlorpyrifos. Washington, DC: Office of Prevention, Pesticides and Toxic Substances, Office of Pesticide Programs, U.S. Government Printing Office. 2006. Disponível em: <https://www3.epa.gov/pesticides/chem_search/ reg_actions/reregistration/red_PC-059101_1-Jul-06.pdf >. Acesso em: 10 nov. 2014.

VIDA, J.B.; ZAMBOLIM, L; TESSMANN, D.J.; BRANDÃO FILHO, J.U.T.; VERZIGNASSA, J.R.; CAIXETA, M.P. Manejo de Doenças de Plantas em Cultivo Protegido. Fitopatologia Brasileira, v. 29, n.4, p.355-372, 2004. 